Print ISSN: 2288-4637 / Online ISSN 2288-4645

doi:10.13106/jafeb.2019.vol6.no3.91

\title{
Executive Compensation in Korea: Evidence from a New Mandatory Disclosure*
}

\author{
Jae Hyun GWON ${ }^{1}$, Byoung Soon MOON ${ }^{2}$
}

Received: May 29, 2019 Revised: June 23, 2019 Accepted: July 13, 2019

\begin{abstract}
This paper finds some stylized facts about executive pay in South Korea. Using aggregate data of the listed companies since 2002, we find that 1) the director's remuneration has risen faster than the employee compensation, thus, the pay ratio of executive and employee has escalated from 3.0 to $4.5 ; 2$ ) the executive compensation for large business group fluctuates more widely than that for small and medium enterprises does, hence the pay ratio for large firms changes widely too; 3) the median pay ratio has not grown monotonically but it rather rises to remain still around year 2011, which is accounted for mostly by small and medium enterprises. New information on executive compensation by compulsory disclosure starting from 2013 made further analysis of CEO compensation attainable. Based on the conventional regression analysis for 2013-2017, we find that 1 ) the elasticity of CEO pay with respect to firm value is about 0.18 ; 2 ) the volatility of stock return is negatively related to CEO pay; 3 ) contemporaneous stock return is positively associated with the pay; 4) there is insufficient evidence that large business groups pay their CEOs more than small and medium enterprises do. These results are robust under various model specifications.
\end{abstract}

Key Words: Executive Compensation, Pay-Performance Sensitivity, Large Business Group, Chaebol.

JEL Classification Code: G30, D22, J31, J33, M12, M52.

\section{Introduction}

Global financial crisis of 2007-2009 revisited the practice of executive compensation. Executive pay is presumably thought to be tied to firm value. However, what played out

* This work was supported by Incheon National University Research Grant in 2017. It was originally titled "Executive Compensation in South Korea: Evidence from New Mandatory Disclosure Since 2013" to be presented at 2019 International Conference on Business and Economics (ICBE2019), Yeosu, South Korea. We appreciate all the comments from the conference session and the anonymous referees.

1 First Author. Assistant Professor, School of Northeast Asian Studies, Incheon National University. [Postal Address: 119 Academy-ro, Yeonsu-gu, Incheon 22012, Republic of Korea]. Email: gwon@inu.ac.kr

2 Corresponding Author. Senior Consultant, LG Economic Research Institute. [Postal Address: Yeoui-daero 128, East Tower 33F (LG Twin Towers), Yeoungdeungpo-gu, Seoul 07336, Republic of Korea]. Email: psmoon@Igeri.com

() Copyright: Korean Distribution Science Association (KODISA)

This is an Open Access article distributed under the terms of the Creative Commons Attribution NonCommercial License (https://creativecommons.org/licenses/by-nc/4.0/) which permits unrestricted nocommercial use, distribution, and reproduction in any medium, provided the original work is properly cited. during the crisis appeared far from this theoretical view. Managers of some poorly performing firms, even under the bailout program in progress, seemed to be excessively compensated. Public anger was elevated.

There had been few issues on regulating "overcompensated" executives in Korea until the late 1990s. Around 2013, however, executive compensation came to public attention since a mandatory disclosure of executive compensation was enacted. The pay discrepancy between executives and rank-and-file employees began to receive public attention, which made high-paid executive concern public antipathy.

When it comes to a large conglomerate business group in South Korea, also known as chaebol, executive compensation becomes a grave concern. Owner-managers in control of a large business groups are suspected to pay themselves excessively using the corporate network of affiliate firms. It is controversial whether a CEO of the business group gets paid "overly" or not.

Limited information on directors' remuneration has been available by mandatory disclosure since 2002. Only aggregate amount of compensation on executives, 
independent directors, and auditors has been reported, respectively. In 2013, the disclosure rule of Capital Market and Financial Investment Act was amended that pay details on individual director became public. With new information on executive pay, this paper is to find out empirical facts pertaining to the level and the structure of executive pay. In addition, we are supposed to analyze how executive compensation changes with respect to some relevant factors brought up by previous literature. The elasticity of CEO pay with respect to firm value is our major concern. For international comparison, we analyze the executive data in a way commensurate with core literature.

\section{Literature Review}

Firstly, we measure how much a typical executive is paid each year. Most literature of executive compensation studies the U.S. in which the data is relatively abundant with more details. How CEO compensation has evolved is well documented over there in comprehensive literature (Jensen \& Murphy, 1990; Hall \& Liebman, 1998; Murphy, 1999; Bebchuk \& Grinstein, 2005; Frydman \& Jenter, 2010; Murphy, 2013; Edmans, Gabaix, \& Jenter, 2017). For an instance of the United States, the CEO pay began to rise in the late 1970 and it seems to cease in the 2000s especially for large corporations.

According to the existing literature, we attempt to document the empirical facts about executive compensation in South Korea. To our dismay, we cannot obtain executive compensation before year 2002. Using available data from 2002, we demonstrate that the executive compensation increases faster than the worker pay does. The pay ratio of executive and worker also increases as well. We delve into this fact by firm size to conclude that recent change is led by small- and medium-sized enterprises.

The main objective of this paper is to decompose crosssectional variation in CEO pay. Before analyzing CEO pay sensitivity to firm value, we assess the structure of CEO compensation from 2013. Frydman and Saks (2010) analyze the long-run trends in executive compensation of large American firms from 1936 to 2005. They find the strong relationship between pay and aggregate firm growth due to the aligned managerial incentives such as stock and/or option grants. In contrast, chief executive officers in Korea are paid mainly by salary and bonus. Long-term incentive and option grants are of relatively small importance. A glance at the pay components alludes that the CEO pay-performance sensitivity in Korea is not as high as that in the United States.

In the end, we study what factors are related to CEO compensation. The firm size, measured by capitalized value, is known to be a main factor positively correlated to CEO pay (Roberts, 1956; Murphy, 1985; Baker, Jensen, \& Murphy, 1988; Barro \& Barro, 1990; Murphy, 1999; Gabaix \& Landier, 2008; Frydman \& Saks, 2010; Gabaix, Landier, \& Sauvagnat, 2014). The bigger the firm is, the more the executive pay is. Chief executive officers are incentivized by the compensation package. The power of pay contract does not depend on the level of pay but it depends on how much CEO will get from the increased firm value. The literature documents positive empirical relationship between firm size and CEO compensation. As in the literature, we derive the positive relation between firm size and CEO compensation, but the magnitude is lower than the U.S. one.

The effect of uncertainty surrounding a company on executive compensation is not clear. Theoretically the volatility of stock return is thought to be negatively related to CEO pay (Holmström \& Milgrom, 1987). The CEO compensation, as an optimal incentive contract, divides the business risk between the manager and the owner. Optimal wage contract allocates the uncertainty between the CEO and the investor and the pay-performance sensitivity indicates the CEO's share of risk taking. Holmström and Milgrom (1987) argue that the pay sensitivity falls as the risk rises such that it alleviates the risk burden placed on the manager. Some empirical studies report negative relations (Lambert \& Larcker, 1987; Aggarwal \& Samwick, 1999; Jin, 2002). Some other studies find positive relations (Core \& Guay, 1999; Oyer \& Schaefer, 2005; Coles, Daniel, \& Naveen, 2006; Edmans et al., 2017). No relation or mixed results are identified elsewhere (Garen, 1994; Yermack, 1995; Bushman, Indjejikian, \& Smith, 1996; Ittner, Larcker, \& Rajan, 1997; Conyon \& Murphy, 2000; Edmans, Gabaix, \& Landier, 2009; Cheng, Hong, \& Scheinkman, 2015). With the recent data in Korea, we find that there is a significantly negative relationship between volatility of return and CEO compensation, which conforms to Holmström and Milgrom (1987).

The most distinct feature of our paper is to examine large business group effect on CEO pay. Large conglomerate business groups, chaebols, in South Korea have controlling minority shareholders of founding family members. Family members, as managers, would run the companies, or they can hire professional CEOs on behalf of them. Chaebols would cause agency problems on corporate finance and governance (Gwon, 2015; Kang \& Kim, 2014; Kim \& Lee, 2019). The agency problem suggests those CEOs would be more likely "over-compensated" for private benefit (John, La Porta, \& Lopez-de-Silanes, 2000; Kastiel, 2015). Lee and Choi (2017) find large Korean business groups award the CEOs more than small and medium enterprises do and they suspect the agency problems within chaebols. With the same data Lee and Choi (2017) uses, we arrive at different 
results. The CEOs of large business groups seem to be highly paid, but it is mainly due to the firm size effect. Controlling for firm size, we fail to find significant relationship between CEO pay and large business group.

Section 3 explains the data we use in detail. Legal background for the data, if necessary, is addressed as well. Section 4 describes the empirical results. The level of executive pay is analyzed in section 4.1 from 2002 to 2017. The structure of executive pay is briefly introduced in section 4.2. Followed is the analysis of CEO pay variation in section 4.3

\section{Data}

Mainly we collect three types of variables: Remuneration, company, and performance. Remuneration information encompasses the employee pay, the director compensation, and the CEO disbursement. In pertinent to company facts, we gather the data such as balance sheets, regulatory classification of business groups, employment status, and so forth. Performance refers to the return and its volatility on the traded stocks, which embodies the value resulting from firm's performance.

Table 1: Brief Summary of Related Literature

\begin{tabular}{|c|c|c|}
\hline Topic & Literature & Literature \\
\hline \multirow{7}{*}{$\begin{array}{l}\text { Comprehensive } \\
\text { Studies }\end{array}$} & Jensen \& Murphy (1990) & Estimates of pay-performance relation for CEOs \\
\hline & Hall \& Liebman (1998) & Relationship between firm performance and CEO compensation \\
\hline & Murphy (1999) & Handbook chapter of executive compensation \\
\hline & Bebchuk \& Grinstein (2005) & U.S. executive pay during the period $1993-2003$ \\
\hline & Frydman \& Jenter (2010) & Literature survey on CEO compensation \\
\hline & Murphy (2013) & Handbook chapter updated \\
\hline & Edmans et al. (2017) & Review of empirical and theoretical literature including non-U.S. firms \\
\hline \multirow{23}{*}{ Pay factors } & Roberts (1956) & \multirow{8}{*}{ Positive relationship between firm size and CEO compensation } \\
\hline & Murphy (1985) & \\
\hline & Baker et al. (1988) & \\
\hline & Barro \& Barro (1990) & \\
\hline & Murphy (1999) & \\
\hline & Gabaix \& Landier (2008) & \\
\hline & Frydman \& Saks (2010) & \\
\hline & Gabaix et al. (2014) & \\
\hline & Holmström \& Milgrom (1987) & $\begin{array}{l}\text { Negative relationship between volatility and CEO compensation } \\
\text { (theory) }\end{array}$ \\
\hline & Lambert \& Larcker (1987) & \multirow{3}{*}{ Negative relationship between volatility and CEO compensation } \\
\hline & Aggarwal \& Samwick (1999) & \\
\hline & $\operatorname{Jin}(2002)$ & \\
\hline & Core \& Guay (1999) & \multirow{4}{*}{ Positive relationship between volatility and CEO compensation } \\
\hline & Oyer \& Schaefer (2005) & \\
\hline & Coles et al. (2006) & \\
\hline & Edmans et al. (2017) & \\
\hline & Garen, 1994; Yermack (1995) & \multirow{6}{*}{$\begin{array}{l}\text { No relationship or mixed results between volatility and CEO } \\
\text { compensation }\end{array}$} \\
\hline & Bushman et al. (1996) & \\
\hline & Ittner et al. (1997) & \\
\hline & Conyon \& Murphy (2000) & \\
\hline & Edmans et al. (2009) & \\
\hline & Cheng et al. (2015) & \\
\hline & Lee \& Choi (2017) & $\begin{array}{l}\text { Positive relationship between large business group (chaebol) and } \\
\text { CEO pay }\end{array}$ \\
\hline
\end{tabular}


Remuneration data can be retrieved from the DART (data analysis, retrieval and transfer system) of the Financial Supervisory Service. By the Capital Market and Financial Investment Business Act, publicly traded companies must have their executive compensations posted in annual reports. Instead of hand-collecting pay information from the DART, we use TS2000, a commercial database provided by the Korea Company Information. As to the publicly traded companies, there are three trading boards in which the companies are registered: KOSPI (Korea Composite Stock Market Index), KOSDAQ (Korea Securities Dealers Automated Quotations), and KONEX (Korea New Exchange) markets. KOSPI opened in 1956, KOSDAQ began in 1996, and KONEX commenced recently in 2013. All three boards are run by the company, KRX (Korea Stock Exchange). Unless it confuses, "listed company" is interchangeably used for the publicly traded company in KOSPI, KOSDAQ, or KONEX.

Executive compensation became available from 2002 by the Securities and Exchange Act, the predecessor of current Capital Market and Financial Investment Business Act. Until 2012, only aggregate (or average) compensation was forced to be public, which impeded the research on individual executive pay in Korea. In this sense, information of executive compensation was disclosed partially and imperfectly beforehand. Each firm reported the average compensations by executive directors, independent directors, and auditors, respectively. Most firms reported the average amounts by the basic three classifications. Some firms voluntarily reported the averages using finer classifications. Some other firms already reported the compensations for individual executives. Facing these discrepancies of disclosure, we cannot but define the executive compensation by the highest average director's pay in each year-company. Most times, executive directors are paid more than independent directors or auditors. Our definition of the executive compensation by the highest average director pay is justifiable in this sense.

From 2013, the Capital Market and Financial Investment Act made the information on the individual executive pay public if the executive director is paid no less than 500 million Korean Won (approximately 420 thousand US dollars). If more than five executive directors are paid more than or equal to 500 million Korean Won, the company should disclose individual compensation details for at least top 5 executives in descending order of total remuneration. As we define the executive compensation, we similarly define the CEO pay by the highest compensation on the individual executive counting in only base salary, bonus, and incentive.

To the extent the data is available, we compute the average executive compensation from 2002 to 2017 . For the
CEO compensation, we do the similar calculation from 2013 to 2017. All executive compensations are retrieved from TS2000.

Total amount of employee compensation in each firm is available for the entire time periods, 2002-2017. We identify the total number of employees at the end of each fiscal year and the average worker's compensation as well.

All non-financial companies listed in KOSPI, KOSDAQ, or KONEX are the ones we deal with. Excluded are financial companies such as commercial banks, insurance companies, asset management companies, securities broker-dealers and the like. There are two reasons for exclusion. Firstly, financial intermediaries have different business features and accounting rules. Secondly, by the strict laws in South Korea, financial industry and commercial sector must be separated in terms of ownership and control. We focus on only non-financial listed companies in consideration of accounting consistency and structural division.

Pertaining to company characteristics, we use the industry classification of Korea Standard Industrial Classification by the National Bureau of Statistics (Statistics Korea). The classification is used to control for industry effect in the regression analysis in section 4.3.

As in the previous literature, firm size is known to be associated with executive compensation. For that matter, we use the regulatory definition of business group, which is a de facto firm size by economic influence. TS2000, from fiscal year 2004, offers the categorical variable that denotes this regulatory classification. The companies belonging to the large business group, the most influential chaebol, are defined scrupulously by the Monopoly Regulation and Fair Trade Act every year. The large business groups face restrictive measures-ownership restriction, control restriction, extra mandatory disclosure-on all the subsidiaries including even private firms. Here we define "large corporations" by the companies belonging to the large business groups under the Fair Trade Act. Many, if not most, of those companies are large indeed. For convenience, we refer to these companies as "large" firms unless they are confusing.

Small and medium enterprises are standalone firms with average sales less than certain threshold defined by the Framework Act on Small and Medium Enterprises. The companies classified as small and medium enterprises by this law are usually subsidized by the government in various measures. We call these companies "small" firms.

If a company does not belong to "large" nor "small" corporation, it is likely eligible for the high potential enterprise defined by the Special Act on Support for Human Resources of Small and Medium Enterprises. Once the firm is registered under this special act, it would receive some 
types of support from the government. We denote this kind of company by "medium" firm.

Finally, we obtain market indices on each firm's stock from another source of commercial database, KISVALUE, which is run by NICE information service. Adjusted stock prices at the end of each year and annualized volatility are retrieved from the database. They are in use to construct market return and volatility regarding firm performance and market capitalization.

\section{Results}

\subsection{Level of Executive Pay}

By how much does an executive earn more than an employee? In the United States, the average ratio of CEO pay to non-supervisory worker was 317 times for S\&P 500 index companies in 2017 (according to Executive Paywatch of AFL-CIO). In the U.S., the ratio declined during the World War II and it had been stable from the 1940s and to the mid1970s (Frydman \& Saks, 2010; Edmans et al., 2017). The soring ratio is a quite a new phenomenon, which coincides with the rapid rise in income inequality (Piketty \& Saez, 2003; Piketty, 2014).

In Korea, the average executive pay has been only available since 2002. Individual CEO's pay became publicly available from 2013. This subsection will examine how a typical executive-CEO, president, chairperson, executive director, etc.-is compensated and how much he/she earns compared to a typical employee. Section 4.2 will elaborate on the similar issue with the CEO pay.

Table 2: Annual Compensations and Pay Ratios by Year

(Unit: KRW thousand)

\begin{tabular}{|c|c|c|c|}
\hline Year & $\begin{array}{c}\text { Executive } \\
\text { Compensation }\end{array}$ & $\begin{array}{c}\text { Employee } \\
\text { Compensation }\end{array}$ & Pay Ratio \\
\hline 2002 & 104,935 & 35,100 & 3.0 \\
\hline 2003 & 110,360 & 36,365 & 3.2 \\
\hline 2004 & 121,712 & 37,681 & 3.3 \\
\hline 2005 & 130,029 & 38,605 & 3.5 \\
\hline 2006 & 137,950 & 39,554 & 3.6 \\
\hline 2007 & 149,300 & 40,828 & 3.7 \\
\hline 2008 & 151,024 & 41,042 & 3.7 \\
\hline 2009 & 154,892 & 40,561 & 3.9 \\
\hline 2010 & 153,760 & 40,459 & 3.9 \\
\hline 2011 & 181,308 & 40,435 & 4.6 \\
\hline 2012 & 179,979 & 41,327 & 4.5 \\
\hline 2013 & 192,432 & 41,816 & 4.6 \\
\hline 2014 & 194,364 & 42,598 & 4.5 \\
\hline 2015 & 191,000 & 43,000 & 4.6 \\
\hline 2016 & 195,141 & 43,812 & 4.5 \\
\hline 2017 & 191,496 & 44,046 & 4.5 \\
\hline Growth Rate & $3.83 \%$ & $1.43 \%$ & $2.51 \%$ \\
\hline
\end{tabular}

Note 1: Compensations are denominated in constant Korean Won (using CPI with base year 2015).

Note 2: The compensation and the pay ratio are the median values in each year.

The second column of Table 2 summarizes the median value of average executive pays across publicly traded companies in each year, that is, $\operatorname{median}_{i}($ mean(executive pay) ${ }_{i t}$ ) for each company $i$ and year $t$. In 2002, the representative median executive pay was about KRW 105 million (USD 95,000 approximately). It increased to KRW 191 million at the end of 2017, thus, the executive pay has grown at the annual rate of $3.8 \%$. All kinds of compensations are adjusted for inflation by consumer price index with base year of 2015 .

The third column of Table 2 shows the median value of average worker's compensation, that is, $\operatorname{median}_{i}(\text { mean(worker pay) })_{i t}$ ) for each company $i$ and year $t$. Worker's pay started from KRW 35 million (USD 31,000 approximately) and increased to KRW 44 million at the end of 2017. The annual growth rate of worker pay for entire years is $1.4 \%$. We can infer that income inequality between executives and rank-and-file employees has been intensified from the outset of 2002.

Global financial crisis of 2007-2009 bore on both executive and employee compensation negatively. The impacts, however, were different in the aftermath. Executive pay did not fall in 2009 and it declined in 2010 for once. But it immediately cut back and overshoot in 2011. Worker pay was declining for 2009-2011 consecutively. That explains why employee compensation grew slower than executive compensation.

It is obvious that the pay ratio of executive and employee, $\operatorname{median}_{i}\left(\right.$ mean(executive pay) $_{i t} /$ mean(worker pay) ${ }_{i t}$ ) for company $i$ and year $t$, has been increasing. Figure 1 displays that the pay ratio does not grow continuously though. Pay ratio saw a jump in 2011 and it has been stable afterwards. Is this because the average executive pay rises sharply and remains still? Or is this because more executives began to work for the high-paying companies and then the job shift stopped?

To answer the question, we derive the median pay for average executives and average workers by small, medium, and large corporations, respectively-Remark that this regulatory classification of the business groups. Worker compensation shows differential changes by the regulatory size. Worker pay of large corporations began to rise again from 2011 whereas that of small and medium fell in 2011. 


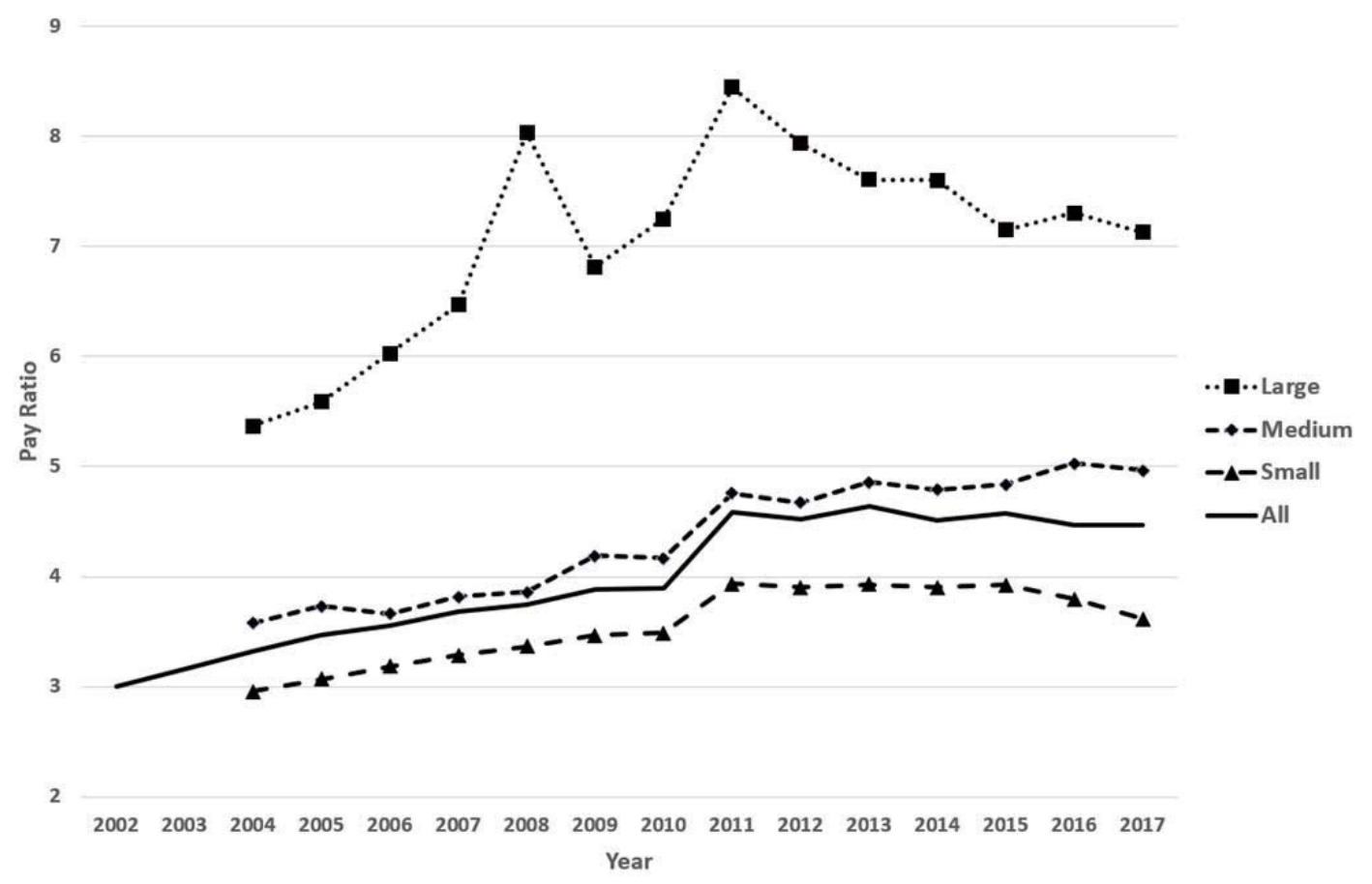

Note: All the ratios are the median values in each year.

Figure 1: Change in the Pay Ratios of Executives and Employees by Firm Size (Listed Firms)

Table 3 and Figure 1 summarize the results. The rise of executive pay level is commonly observed regardless of firm size and it is the main factor that lifted the pay ratio in 2011. Executive pay ratio for large corporation changes more widely than those for small and medium companies. Since we are interested in the typical executive, the median of the pay and the pay ratio are computed (Murphy, 2013). Therefore, the entire median ratio is not heavily influenced by the outliers. As Figure 1 displays, the executive pay ratios for large corporations are greater than 5 all time while those for small and medium enterprises do not exceed 5. If more CEOs participated in large corporations, the pay ratio would have risen despite the stagnant CEO compensation of SMEs. But that did not happen. Drastic change in pay ratio for large corporation would constitute outliers, hence, the second-order factor for the overall pay ratio.

Large corporations pay executives and workers more than small and medium enterprises. The pay ratio of large corporation is higher than that of SMEs. What about the change in the pay levels? Table 3 evidences that SME has raised the pays for both executives and workers than the large corporation does. Even though large companies demonstrate high level of compensation and pay ratio, we conclude that the rise of compensation and pay ratio was mainly led by SMEs.
Table 3: Annual Compensations on Executives and Employees by Firm Size

\begin{tabular}{|c|c|c|c|c|c|c|}
\hline \multirow{2}{*}{ Year } & \multicolumn{3}{|c|}{ Executive } & \multicolumn{3}{c|}{ Emit: KRW thousand) } \\
\cline { 2 - 7 } & Large & Medium & Small & Large & Medium & Small \\
\hline 2004 & 296,986 & 143,299 & 100,929 & 53,706 & 39,861 & 34,443 \\
\hline 2005 & 313,478 & 142,760 & 108,358 & 54,838 & 40,331 & 35,319 \\
\hline 2006 & 352,859 & 147,004 & 119,146 & 56,426 & 41,422 & 36,275 \\
\hline 2007 & 341,619 & 161,941 & 123,976 & 55,451 & 43,810 & 37,431 \\
\hline 2008 & 435,646 & 168,150 & 124,304 & 58,672 & 43,041 & 37,772 \\
\hline 2009 & 373,943 & 182,335 & 128,220 & 56,623 & 43,444 & 37,003 \\
\hline 2010 & 377,376 & 180,047 & 128,109 & 53,816 & 43,087 & 37,439 \\
\hline 2011 & 441,315 & 197,430 & 143,508 & 55,552 & 42,231 & 36,952 \\
\hline 2012 & 417,919 & 199,261 & 143,703 & 56,710 & 43,442 & 37,194 \\
\hline 2013 & 419,182 & 220,217 & 151,966 & 58,265 & 43,730 & 37,737 \\
\hline 2014 & 430,019 & 218,534 & 152,068 & 58,674 & 44,664 & 38,109 \\
\hline 2015 & 423,813 & 220,920 & 153,825 & 61,000 & 46,018 & 38,840 \\
\hline 2016 & 474,631 & 230,762 & 147,569 & 61,404 & 47,910 & 39,616 \\
\hline 2017 & 404,094 & 230,254 & 144,535 & 60,988 & 47,605 & 39,975 \\
\hline $\begin{array}{c}\text { Growth } \\
\text { Rate }\end{array}$ & $2.2 \%$ & $3.4 \%$ & $2.6 \%$ & $0.9 \%$ & $1.3 \%$ & $1.1 \%$ \\
\hline
\end{tabular}

Note 1: All compensations are simple medians denominated in constant Korean Won (using CPI with base year 2015).

Note 2: "Large" stands for large corporation, "Medium" for high potential enterprise, and "Small" for small and medium enterprise. 


\subsection{The Structure of CEO Pay}

As noted, provided that the executive directors are paid more than KRW 500 million, compensations must be disclosed by individual executive from year 2013. The pay components encompass base salary, bonus, incentive, the value of exercised stock options, severance pay, other earned income, and other non-earned income. We remark that the value of exercised options differs from the grantdate value of options.

We can hardly tell who the CEO is simply by job title. As in conventional studies, we define the highest paid executive as the CEO in each company-year. Only base salary, bonus, and incentive are of consideration when we compute the total executive pay. Table 4 shows the structure of CEO compensation.

Bonus is usually contracted to be a proportion of the base salary in Korea. Payment of bonus is legally binding; thus, it could be construed a part of salary. Incentive is usually awarded to the team or the individuals when the target performance is achieved. However, we are not ascertained whether the incentive is long-term or not.

As seen in Table 4, the sum of salary and bonus forms 74-80 percent of CEO compensation. Adding incentive, the sum amounts to 90-95 percent. The structure of Korea's CEO compensation differs from the United States. Rather it resembles the CEO pay structure of Belgium or France (Edmans et al., 2017).

The structure of CEO compensation depicted by Table 4 alludes that CEO pay is loosely tied to the firm performance in comparison to the United States. Section 4.3 measures the pay sensitivity to firm performance rigorously.

Table 4: The Structure of CEO Compensation by Year

(Units: \%, KRW million)

\begin{tabular}{|l|c|c|c|c|c|}
\hline \multirow{2}{*}{\multicolumn{1}{c|}{ Component }} & \multicolumn{5}{|c|}{ Year } \\
\cline { 2 - 6 } & $\mathbf{2 0 1 3}$ & $\mathbf{2 0 1 4}$ & $\mathbf{2 0 1 5}$ & $\mathbf{2 0 1 6}$ & $\mathbf{2 0 1 7}$ \\
\hline Salary & $62.2 \%$ & $61.1 \%$ & $56.4 \%$ & $56.7 \%$ & $55.0 \%$ \\
\hline Bonus & $15.5 \%$ & $19.5 \%$ & $17.6 \%$ & $21.3 \%$ & $24.8 \%$ \\
\hline Incentive & $9.6 \%$ & $3.0 \%$ & $1.7 \%$ & $1.1 \%$ & $1.3 \%$ \\
\hline Exercised Options & $4.3 \%$ & $4.3 \%$ & $0.9 \%$ & $2.2 \%$ & $6.1 \%$ \\
\hline Severance Pay & $2.7 \%$ & $9.1 \%$ & $18.0 \%$ & $16.6 \%$ & $9.2 \%$ \\
\hline Other Earned Income & $5.5 \%$ & $2.9 \%$ & $4.6 \%$ & $1.8 \%$ & $3.4 \%$ \\
\hline $\begin{array}{l}\text { Other Non-Earned } \\
\text { Income }\end{array}$ & $0.2 \%$ & $0.0 \%$ & $0.8 \%$ & $0.5 \%$ & $0.3 \%$ \\
\hline Total & 427,865 & 468,121 & 522,151 & 552,638 & 633,716 \\
\hline$\#$ \#bservations) & 357 & 401 & 451 & 475 & 496 \\
\hline
\end{tabular}

Note 1: The CEO is defined by the highest paid executive of the firm in each year.

Note 2: Total compensations are denominated in constant Korean Won (using CPI with base year 2015).

Note 3: Sum of each component divided by total CEO compensations is denoted in terms of percentage for each year.

\subsection{Cross-Sectional Variation in CEO Pay}

According to Edmans et al. (2017), we estimate the elasticity of CEO pay with respect to firm value. Firm value is the market value of asset consisting of equity and liability. The value of equity is approximated by the market value of stocks. The average annual value of common stocks and preferred stocks is used for the market value of equity. The value of liability is substituted by book value. Subtracting book value of equity and net deferred taxes from book value of assets, we compute the book value of liability. In short,

firm value $=$ market value of equity $+[$ book value of assets - (book value of equity + net deferred taxes)]

In principle, we estimate the pay elasticity by estimating $\alpha$ of the following regression,

$$
\ln (\text { CEO pay })_{t}=\alpha \ln (\text { Firm value })_{t-1}+\text { other factors }+\varepsilon_{t}
$$

for year $t=2013, \ldots, 2017$ where CEO pay is the sum of salary, bonus, and incentive.

Salary and bonus are contracted usually at the end of previous year or at the beginning of current year. They would be affected by the firm value in the preceding year, which places the current CEO pay on the left of regression equation (1) and the previous firm value on the right.

Many other factors that might affect CEO compensation receive consideration to be controlled for. According to Edmans et el. (2017), for instances, stock returns of this year and previous years, stock return volatility, CEO's characteristic, type of industry might bear on CEO pay.

Table 5: Cross-Sectional Variation in CEO Pay

\begin{tabular}{|c|c|c|c|c|c|c|c|}
\hline & \multicolumn{7}{|c|}{ In(Total Pay $\left.{ }_{t}\right)$} \\
\hline & (A) & (B) & (C) & (D) & (E) & (F) & (G) \\
\hline \multirow[t]{2}{*}{ In(Firm Value $\left._{t-1}\right)$} & $0.218^{\star \star \star}$ & $0.214^{\star \star \star}$ & $0.201^{\star \star \star}$ & $0.206^{\star \star \star}$ & $0.201^{\star \star x}$ & $0.186^{\star \star \star}$ & $0.181^{\star \star \star}$ \\
\hline & {$[0.010]$} & [0.010] & {$[0.011]$} & {$[0.011]$} & [0.011] & {$[0.014]$} & {$[0.014]$} \\
\hline \multirow[t]{2}{*}{ Volatility $_{t-1}$} & $-0.003^{\text {ᄎᄎ }}$ & $-0.003^{\text {t丸k }}$ & $-0.003^{\star \star \star \alpha}$ & $-0.003^{\text {*ᄎᄎ }}$ & $-0.003^{\text {*k木 }}$ & $-0.002^{\star \star \star}$ & $-0.005^{* k \star}$ \\
\hline & [0.001] & [0.001] & \begin{tabular}{|l}
$0.001]$ \\
\end{tabular} & {$[0.001]$} & {$[0.001]$} & {$[0.001]$} & [0.001] \\
\hline \multirow[t]{2}{*}{$\ln \left(\mathrm{Age}_{t}\right)$} & & $0.376^{\text {ᄎ }}$ & $0.343^{\star \star}$ & $0.410^{\star \star \star}$ & $0.322^{\star \star}$ & $0.332^{\star \star}$ & 0.170 \\
\hline & & [0.110] & [0.114] & [0.112] & [0.116] & {$[0.116]$} & [0.115] \\
\hline \multirow[t]{2}{*}{ Female $_{t}$} & & & 0.148 & 0.161 & 0.125 & 0.127 & 0.219 \\
\hline & & & [0.139] & {$[0.137]$} & {$[0.137]$} & {$[0.137]$} & {$[0.137]$} \\
\hline \multirow[t]{2}{*}{ Chaebol $_{t}$} & & & & & & 0.094 & 0.045 \\
\hline & & & & & & [0.052] & [0.053] \\
\hline \multirow[t]{2}{*}{$\ln \left(1+\right.$ Return $\left._{t}\right)$} & & & & & & & $0.156^{\star \star \star}$ \\
\hline & & & & & & & [0.047] \\
\hline \multirow[t]{2}{*}{$\ln \left(1+\right.$ Return $\left._{t-1}\right)$} & & & & & & & 0.010 \\
\hline & & & & & & & {$[0.032]$} \\
\hline \multirow[t]{2}{*}{$\ln \left(1+\right.$ Return $\left._{t-2}\right)$} & & & & & & & 0.074 \\
\hline & & & & & & & {$[0.044]$} \\
\hline \multirow[t]{2}{*}{ Constant } & 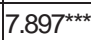 & $6.456^{\star \star \star}$ & $6.952^{\star \star \star}$ & $6.781^{\star \star \star}$ & $7.286^{\star x+}$ & $7.650^{\star \star \star}$ & $8.545^{\star \star \star}$ \\
\hline & {$[0.280]$} & [0.524] & [0.544] & {$[0.537]$} & [0.654] & [0.684] & [0.683] \\
\hline
\end{tabular}




\begin{tabular}{|c|c|c|c|c|c|c|c|}
\hline Year FEs & & & & Yes & Yes & Yes & Yes \\
\hline Industry FEs & & & & & Yes & Yes & Yes \\
\hline$\#$ (observations) & 1,925 & 1,912 & 1,646 & 1,646 & 1,646 & 1,646 & 1,494 \\
\hline $\mathrm{R}^{2}$ & 0.209 & 0.205 & 0.197 & 0.222 & 0.242 & 0.244 & 0.254 \\
\hline
\end{tabular}

CEO pay as a managerial incentive depends on the firm performance of this year and the previous years. The firm performance is measured by the return on stock. Here, log returns are calculated from the stock prices at the end of fiscal years. Since long-term pay incentive might depend on the lagged performance, we include the lagged returns up to two years in specification $(G)$ of Table 5 .

Given a year, the volatility is the standard deviation of daily stock returns multiplied by the square root of actual trading days. Log return, $\ln \left(1+\right.$ return $\left._{t}\right)$, is computed by taking the logarithmic ratio of stock price at $t$ and stock price at ( $t$ 1).

Table 5 shows the CEO pay elasticity with respect to the firm size is significantly positive. Controlling for other factors, we obtain the strong positive elasticity which is robust to regression specifications. This finding is consistent with the literature in section 2. The pay-size elasticity is about 0.2 , which means that CEO compensation rises by 0.2 percent as firm value increases by 1 percent. We remark that the elasticity is less than the half of the U.S. case (Edmans et al., 2017).

Holmström and Migrom (1987) predict that the incentive power of CEO pay fall when the risk of the firm increases. Our empirical finding fits the theoretical exploration. There is a negative relationship between firm risk and CEO pay. The relationship is robust even when we include CEO characteristics, time effects, industry effects, and stock returns. Our finding accords with the literature documenting this negative relationship between volatility and CEO pay (Lambert \& Larcker, 1987; Aggarwal \& Samwick, 1999; Jin, 2002).

CEOs are more likely to get paid higher as they grow older (regression A-F). Since the age is presumably proportional to job-specific skill accumulation, this result might seem natural. However, when we include the current and past stock returns, the age effect diminishes out (regression G). CEO's age effect is reported to be negatively correlated with pay insignificantly when we include CEO's tenure (Edmans et al., 2017). Lack of the information on CEO tenure, controlling for other factors, we are not ascertained that South Korea's CEOs get paid higher as they grow older.

Female CEOs seem to get paid more than male CEOs but this finding is not significant for all regression specification. Contrary to rank-and-file employee compensation, there is a female wage premium in CEO market even though the magnitude is statistically weak. Our finding is consistent with Bertrand and Hallock (2001). In our sample, female CEOs are very few and they account for only 2.0 percent of all CEOs.

Controlling for year and industry effects, we find that CEO pay is positively related to the previous performance but the relationship to the previous years is statistically insignificant (regression G). In section 4.2, we briefly remarked that incentive pay in Korea might not be structured for long-term impetus. This insignificant result conforms to our conjecture.

The last but not the least finding is that CEOs working for a large business group, chaebol, seem to get paid more but the relationship is not significant (regression $F$ and $G$ ). Large corporations used to award CEO more than small and medium enterprises. We verify the same fact when we examine the level of executive pay in section 4.1. Since conglomerate family business, chaebol, owns many large corporations, we need to differentiate the firm-size effect and pure chaebol effect. Controlled for the firm-size effect, if chaebol-affiliated companies pay CEOs more, we may suspect that the CEO gets paid more simply because he is affiliated with family member. This is a classical issue of the agency problem (Jensen \& Meckling, 1976; Bebchuk \& Fried, 2003).

In specification $F$ and $G$, we have In(firm value) for firm size while we add categorical variable for large business group, chaebol. Pure effect of large business group is insignificant. Lee and Choi (2017) note that large-businessgroup-affiliated firms pay higher compensation for executives than non-large-business-group-affiliated firms. However, controlling for firm-size effect, we can hardly conclude that the agency problem within large business groups leads to overly compensation on their CEOs.

\section{Conclusion and Discussion}

This paper investigates how much executives are paid (level) and how they are paid (change). The levels of executive compensation are examined by descriptive statistics with aggregate data for the period 2002-2007. The analysis of cross-sectional variation for 2013-2017 shows the main factors that associate with chief executive officer's compensation.

Pertaining to aggregate executive compensation, we would like to highlight three facts. Firstly, the executive director's remuneration has been increasing faster than the worker's compensation. We can reconfirm the consequential inequality by the fact that the median pay ratio of executive and worker pay was 3.0 in 2002 and rose to 4.5 in 2017. 
Secondly, the median executive pay of large corporations is exposed to uncertainty more than that of small and medium enterprises. There was evidently negative pay shock during the recent global financial crisis. Even though the pay of large corporations cut back after the crisis, it tends to decline after the peak of 2011. Thirdly, small- and mediumsized corporations were hit by the crisis too. However, since executives and workers were affected by the similar magnitude, the median pay ratio for SMEs did not drop. Rather the ratio had been increasing until 2011 and then remains standstill. The overall pay ratio follows the similar change in pattern such that executives from SMEs lead the overall changes in the median pay ratio.

Let us discuss the limitation of our findings on executive pay levels. In section 4.1, we report the median values of compensations and pay ratios. The means are greater than the medians since outliers taking on extremely high values make the distribution right skewed. And the median is more stable than the mean. Murphy (2013) remarks that mean pay is a better indicator for aggregate levels of CEO pay while median pay is appropriate for a typical CEO. In the similar spirit, the median weighted with the number of employees would be a better measure for a typical worker and the median weighted with the number of executives would work better for a typical executive. Admittedly, we have insufficient information on the number of executives. That is why we keep to the simple median instead of other weighted medians.

Now we sum up the main results from the cross-sectional variation analysis. Mandatory disclosure from year 2013 enables us to delve into compensation breakdowns such as base, bonus, incentive, exercised value of stock options, and other incomes. Firstly, we successfully derive the CEO pay elasticity with respect to the firm value, which is about $0.18-0.20$. It means that one percent increase in firm value associates 0.18 percent increase in CEO pay. It is arguable that this level of elasticity is enough to empower the CEO to work hard. What we are sure at least is that this elasticity is lower than the half of the United States case. Secondly, the underlying uncertainty surrounding company is negatively associated with the CEO pay in South Korea. It fits the theory by Holmström and Migrom (1987) but it differs from the U.S. empirical study by Edmans et al. (2017). Thirdly, there is a lingering effect of previous firm performance on the current CEO pay. In our data, the lasting effect is so short that the CEO compensation is not significantly affected by the firm performance more than one year ago. It might be due to the Korean firm's executive pay structure that consists mostly of base salary and the like. Finally, we find a statistically insignificant but economically significant result. Netting out firm-size effect, we measure whether a large business group, chaebol, awards the CEO more or not. We fail to conclude that chaebols pay their executives more. Seemingly high pay on CEOs of chaebols would be owing to their large company size.

There are notable things. In section 4.2, we decompose the CEO pay into base salary, bonus, incentive, value of exercised stock options, and other components. This paper does not deal with the grant-date value of stock options. The value of stock option as compensation package must be measured when options are granted. There are two frequently used methods in the literature. The first one is to apply Black-Sholes option pricing into executive stock option grants (Black \& Scholes, 1973). It easily approximates the precise option value, but the approximation does not work well for some complicated options beyond simple ones. Moreover, Black-Scholes formula is known to overstate the true value (Lambert, Larcker, \& Verrecchia, 1991; Carpenter, 1998; Meulbroek, 2001; Hall \& Murphy, 2002; Ingersoll, 2006; Carpenter, Stanton, \& Wallace, 2010, 2017). In place of Black-Scholes formula, we can draw on numerical method alternatively. Computational discrete-time model can be applied to the stock-option pricing (Cox, Ross, \& Rubinstein, 1979).

Executive personal information is not codified in TS2000 and stored in text format. In section 4.3, we could not eliminate idiosyncratic CEO fixed effect due to a lack of readily available CEO data. CEO fixed effect needs to be controlled for where we suspect that the executives working for large companies might be of higher skills and/or higher ability selectively. Education level and tenure are hard to derive from the database either.

The mandatory disclosure of executive compensation does not apply to the executives paid less than KRW 500 million or those who paid by private firms. Technically speaking, it is left-censored data even though some companies do reveal their individual executive pay voluntarily.

Owner-managers of a family business group might also hide their compensation in a way that they are paid little in public subsidiaries but paid much in private subsidiaries. The executive data might have this sort of selection problem.

Table 5 is the regression that shows statistical relationship between variables. It is worth to note that we cannot draw a solid causal inference from the regression results. Causal relationship would be attainable under the circumstances of natural experiments.

\section{References}

Aggarwal, R. K. \& Samwick, A. A. (1999). The other side of the trade-off: The impact of risk on executive compensation. Journal of Political Economy, 107(1), 65105. 
Barro, J. R., \& Barro, R. J. (1990). Pay, performance, and turnover of bank CEOs. Journal of Labor Economics, 8(4), 448-481.

Baker, G. P., Jensen, M. C., \& Murphy, K. J. (1988). Compensation and incentives: Practice vs. theory. Journal of Finance, 43(3), 593-616.

Bebchuk, L. A., \& Fried, J. M. (2004). Executive compensation as an agency problem. Journal of Economics Perspectives, 117(2), 71-92.

Bebchuk, L. A., \& Grinstein, Y. (2005). The growth of executive pay. Oxford Review of Economic Policy, 21(2), 283-303.

Bertrand, M., \& Hallock, K. F. (2001). The gender gap in top corporate jobs. Industrial and Labor Relations Review, 55(1), 3-21.

Black, F., \& Scholes, M. (1973). The pricing of options and corporate liabilities. Journal of Political Economy, 81(3), 637-654.

Bushman, R. M., Indjejikian, R. J., \& Smith, A. (1996). CEO compensation: The role of individual performance evaluation. Journal of Accounting Economics, 21(2), 161193.

Carpenter, J. N. (1998). The exercise and valuation of executive stock options. Journal of Financial Economics, 48(2), 127-158.

Carpenter, J. N., Stanton, R., \& Wallace, N. (2010). Optimal exercise of executive stock options and implications for firm cost. Journal of Financial Economics, 98(2), 315-337.

Carpenter, J. N., Stanton, R., \& Wallace, N. (2017). Estimation of employee stock option exercise rates and firm cost (Working Paper). New York, NY: New York University.

Cheng, I. H., Hong, H., \& Scheinkman, J. A. (2015). Yesterday's heroes: Compensation and risk at financial firms. Journal of Finance, 70(2), 839-879.

Coles, J. L., Daniel, N. D., \& Naveen, L. (2006). Managerial incentives and risk-taking. Journal of Financial Economics, 79(2), 431-468.

Conyon, M. J., \& Murphy, K. J. (2000). The prince and the pauper? CEO pay in the U.S. and U.K.. Economic Journal, 110(467), 640-671.

Core, J. E., \& Guay, W. R. (1999). The use of equity grants to manage optimal equity incentive levels. Journal of Accounting Economics, 28(2), 151-184.

Cox, J. C., Ross, S. A., \& Rubinstein, M. (1979). Option pricing: A simplified approach. Journal of Financial Economics, 7(3), 229-263.

Edmans, A., Gabaix, X., \& Jenter, D. (2017). Executive compensation: A survey of theory and evidence.

Edmans, A., Gabaix, X., \& Landier, A. (2009). A multiplicative model of optimal CEO incentives in market equilibrium. Review of Financial Studies, 22(12), 48814917.

Frydman, C., \& Jenter, D. (2010). CEO compensation. Annual Review of Financial Economics, 2(1), 75-102.

Frydman, C., \& Saks, R. (2010). Executive compensation: A new view from a long-term perspective, 1936-2005. Review of Financial Studies, 23(5), 2099-2138.

Gabaix, X., \& Landier, A. (2008). Why has CEO pay increased so much? Quarterly Journal of Economics, 123(1), 49-100.

Gabaix, X., Landier, A., \& Sauvagnat, J. (2014). CEO pay and firm size: An update after the crisis. Economic Journal, 124(574), 40-59.

Garen, J. E. (1994). Executive compensation and principalagent theory. Journal of Political Economy, 102(6), 11751199.

Gwon, J. H. (2015). Formation of corporate governance in Korea: The rise of chaebols (1910-1980). East Asian Journal of Business Management, 5(4), 67-72.

Hall, B. J., \& Liebman, J. B. (1998). Are CEOs really paid like bureaucrats? Quarterly Journal of Economics, 112(3), 653-691.

Hall, B. J., \& Murphy, K. J. (2002). Stock options for undiversified executives. Journal of Accounting Economics, 33(1), 3-42.

Holmström, B., \& Milgrom, P. (1987). Aggregation and linearity in the provision of intertemporal incentives. Econometrica, 55(2), 308-328.

Ingersoll, J. (2006). The subjective and objective evaluation of incentive stock options. Journal of Business, 79(2), 453-488.

Ittner, C. D., Larcker, D. F., \& Rajan, M. V. (1997). The choice of performance measures in annual bonus contracts. Accounting Review, 72(2), 231-255.

Jensen, M. C., \& Meckling, W. H. (1976). Theory of the firm: Managerial behavior, agency costs and ownership structure. Journal of Financial Economics, 3(4), 305-360.

Jensen, M. C., \& Murphy, K. J. (1990). Performance pay and top-management incentives. Journal of Political Economy, 98(2), 225-264.

Jin, L. (2002). CEO compensation, diversification, and incentives. Journal of Financial Economics, 66(1), 29-63.

Johnson, S., La Porta, R., Lopez-de-Silanes, F., \& Shleifer, A. (2000). Tunneling. American Economic Review, 90(2), 22-27.

Kang, S.-A., \& Kim, T.-J. (2014). A study of the relationship between corporate governance and real earnings management: Based on foreign investors and growth. Journal of Distribution Science, 12(4), 85-92

Kastiel, K. (2015). Executive compensation in controlled companies. Indiana Law Journal, 90(3), 1131-1175. 
Kim, S.-S., \& Lee, J.-H. (2019). How does corporate social responsibility affect asymmetric information: Evidence from Korean retail industry, Journal of Distribution Science, 17(2), 5-11.

Lambert, R. A., \& Larcker, D. F. (1987). An analysis of the use of accounting and market measures of performance in executive compensation contracts. Journal of Accounting Research, 25, 85-125.

Lambert, R. A., Larcker, D. F., \& Verrecchia, R. (1991). Portfolio considerations in valuing executive compensation. Journal of Accounting Research, 29(1), 129-149.

Lee, C. M., \& Choi, H. S. (2017). The determinants of executive compensations at listed firms in Korea. Korean Journal of Law and Economics, 14(1), 117-168.

Meulbroek, L. K. (2001). The efficiency of equity-linked compensation: Understanding the full cost of awarding executive stock options. Financial Management, 30(2), 530.

Murphy, K. J. (1985). Corporate performance and managerial remuneration: An empirical analysis. Journal of Accounting Economics, 7(1), 11-42.

Murphy, K. J. (1999). Executive compensation. In O. C. Ashenfelter, \& D. Card (Eds.), Handbook of Labor
Economics (Vol. 3B, pp.2485-2563). Amsterdam, Netherlands: Elsevier/North-Holland.

Murphy, K. J. (2013). Executive compensation: Where we are, and how we got there. In G. M. Constantinides, M. Harris, \& R. M. Stulz (Eds.), Handbook of the Economics of Finance (Vol. 2A, pp.211-356). Amsterdam, Netherlands: Elsevier/North-Holland.

Oyer, P., \& Schaefer, S. (2005). Why do some firms give stock options to all employees?: An empirical examination of alternative theories. Journal of Financial Economics, 76(1), 99-133.

Piketty, T. (2014). Capital in the 21st century (A. Goldhammer, Trans.). Cambridge, MA: Harvard University Press (Original work published 2013).

Piketty, T., \& Saez, E. (2003). Income inequality in the U.S. 1913-1998. Quarterly Journal of Economics, 118(1), 1-39.

Roberts, D. R. (1956). A general theory of executive compensation based on statistically tested propositions. Quarterly Journal of Economics, 70(2), 270-294.

Yermack, D. (1995). Do corporations award CEO stock options effectively? Journal of Financial Economics, 39(2), 237-269. 